\title{
Laba Bersih, Rasio Hutang Atas Modal, Arus Kas Operasi dan Harga Saham Bank Umum Milik Negara
}

\author{
Lusi Rahayu 1, Mulyadi 2, Edy Supriyadi ${ }^{3}$ \\ ${ }^{123}$ Universitas Pancasila, Jakarta, Indonesia
}

\section{A R T I C L E I N F O \\ JEL Classification: G14, M41}

Key words:

net profit, debt to equity ratio, cash flow of operation, price stock

\begin{abstract}
A B S T R A C T
The capital market is one of investment alternative that able to yield optimal advantage for investor. Each investor is requiring of relevant information with transaction development in stock. Net profit, debt to equity ratio and cash flow of operation was one of most important information on company performance. This research aims to examine : (1) the influence of net profit to price stock 4 goverment bank in 2009-2016, (2) the influence of debt to equity ratio to price stock 4 government bank in 2009-2016, (3) the influence of cash flow of operation to price stock 4 government bank in 2009-2016, (4) the influence of net profit,debt to equity ratio and cash flow of operation together to price stock 4 government bank in 2009-2016. Data in this research is secondary data obtained from the companys annual financial statement in the indonesia stock exchange (idx). This type of research of causality. This research was conducted by using sample of 4 government bank listed in indonesia stock exchange periode 2009-2016. The statistic method used are analysis multiple linear regression. This study concluded that net profit have a possitive affect on price stock, debt to equity ratio have a positive influence on price stock, cash flow of operation have a possitive influence on price stock and net profit, debt to equity ratio, cash flow of operation are simultaneosly have a positif influence on price stock 4 government bank in 2009-2016.
\end{abstract}

\begin{abstract}
A B S T R A K
Pasar modal merupakan salah satu alternatif pilihan investasi yang dapat menghasilkan tingkat keuntungan optimal bagi para investor. Setiap investor sangat membutuhkan informasi yang relevan dengan perkembangan transaksi di bursa. Laba bersih, rasio hutang terhadap modal dan arus kas operasi merupakan salah satu informasi penting yang dapat digunakan oleh investor untuk menilai kinerja perusahaan. Penelitian ini bertujuan untuk mengetahui: (1) pengaruh laba bersih terhadap harga saham 4 bank bumn periode 2009-2016, (2) pengaruh rasio hutang atas modal terhadap harga saham 4 bank bumn periode 2009-2016, (3) pengaruh arus kas operasi terhadap harga saham 4 bank bumn periode 2009-2016, (4) pengaruh laba bersih,rasio hutang atas modal dan arus kas operasi secara bersama-sama terhadap harga saham 4 bank bumn periode 2009-2016. Data-data dalam penelitian ini merupakan data sekunder yang diperoleh dari laporan keuangan tahunan perusahaan yang terdaftar di bursa efek indonesia. Penelitian ini dilakukan dengan menggunakan sampel berjumlah 4 bank bumn yang terdaftar di bursa efek indonesia periode 20092016. Metode statistik yang digunakan adalah analisis regresi linier berganda. Hasil penelitian menunjukkan bahwa laba bersih berpengaruh terhadap harga saham,rasio hutang terhadap modal berpengaruh terhadap harga saham,arus kas berpengaruh terhadap harga saham dan laba bersih,rasio hutang atas modal,arus kas secara simultan berpengaruh terhadap harga saham 4 bank bumn yang terdaftar di bursa efek indonesia tahun 2009-2016.
\end{abstract}

\section{PENDAHULUAN}

Indonesia merupakan salah satu negara yang memiliki kondisi ekonomi yang cukup stabil untuk berinvestasi dan berbisnis. Setelah diterpa krisis ekonomi pada tahun 1998, perekonomian Indonesia perlahan menunjukkan peningkatan. Salah satu tulang punggung perekonomian di Indonesia dalam rangka untuk membangun sistem perekonomian yang lebih baik adalah

* Email Korespondensi: ${ }^{1}$ rahayulusi@yahoo.com 
perusahaan. Semakin banyak perusahaan yang tumbuh dan berkembang akan memberikan pengaruh positif terhadap pengembangan pemulihan perekonomian Indonesia (Taufiqkurochman dan Konadi,2012:108). Demi pengembangan perekonomian Indonesia, para pemilik perusahaan diarahkan ke pasar modal dimana pasar modal merupakan sarana bagi pihak-pihak yang memiliki dana lebih untuk melakukan investasi dalam jangka waktu panjang (Maskun,2012: 85).

Saham merupakan tanda bukti penyertaan kepemilikan modal atau dana pada suatu perusahaan. Wujud saham adalah selembar kertas yang tercantum dengan jelas nilai nominal, nama perusahaan dan diikuti dengan hak dan kewajiban yang dijelaskan kepada setiap pemegangnya. Bagi pihak yang memiliki saham akan memperoleh beberapa keuntungan sebagai bentuk kewajiban yang harus diterima yaitu memperoleh

keuntungan, diantaranya memperoleh capital gain yang merupakan keuntungan pada saat saham yang dimiliki akan dijual kembali pada harga saham yang lebih mahal dan keuntungan lainnya yaitu memiliki hak suara bagi pemegang saham jenis common stock (Fahmi, 2013:53).

Informasi mengenai arus kas perusahaan yang terdiri atas arus kas operasi, arus kas investasi dan arus kas pendanaan juga merupakan hal yang penting untuk diperhatikan investor terutama informasi arus kas operasi. Menurut Keiso et al (2008:216) Walaupun laba bersih menyediakan ukuran jangka panjang menyangkut keberhasilan atau kegagalan perusahaan, namun arus kas merupakan darah kehidupan sebuah perusahaan. Tanpa kas, sebuah perusahaan tidak akan bertahan. Titik awal yang baik dalam pemeriksaannya adalah menemukan kas bersih yang disediakan oleh aktivitas operasi. Juga kas bersih yang disediakan oleh aktivitas operasi tinggi, maka hal ini mengindikasikan bahwa perusahaan mampu menghasilkan kas yang mencukupi secara internal dari operasi untuk membayar kewajibannya tanpa harus meminjam dari luar.

Tabel 1.1

Tabel Laba Bersih,DER,Arus Kas Operasi dan Harga Saham 4 Bank BUMN

\begin{tabular}{llccc}
\hline \multirow{2}{*}{ Nama Bank } & Tahun & Laba Bersih & $\begin{array}{c}\text { Debt to Equity } \\
\text { Ratio }\end{array}$ & Arus Kas Operasi \\
\hline Bank Mandiri & 2016 & 14.650 .163 & 5.38 & 41.521 .119 \\
& 2015 & 20.387 .230 & 6.16 & 10.201 .454 \\
& 2014 & 19.954 .783 & 6.65 & 21.091 .691 \\
BTN & 2016 & 2.618 .905 & 10.20 & 9.783 .925 \\
& 2015 & 1.858 .093 & 11.40 & 1.707 .579 \\
& 2014 & 1.115 .625 & 11.80 & 2.049 .009 \\
BNI & 2016 & 11.410 .196 & 5.52 & 15.422 .131 \\
& 2015 & 9.140 .532 & 5.26 & 24.356 .628 \\
BRI & 2014 & 10.829 .379 & 5.50 & 6.103 .708 \\
& 2016 & 26.227 .991 & 5.84 & 21.770 .833 \\
& 2015 & 25.272 .194 & 6.76 & 45.544 .908 \\
\hline
\end{tabular}

Sumber: www.yahoofinance.com 
Tabel 1.1 menyajikan data laba bersih dan harga saham 4 Bank BUMN periode tahun 2009-2016. Dari tabel diatas dapat dilihat pada Bank Mandiri dan BRI terdapat kenaikan laba bersih setiap tahunnya, tetapi berbeda dengan BTN yang mengalami penurunan laba bersih pada tahun 2014 dan BNI yang mengalami penurunan laba bersih pada tahun 2015. Perolehan laba bersih yang meningkat disetiap tahunnya pada Bank Mandiri dan BRI tidak selalu disertai dengan kenaikan harga saham, padahal secara teori kenaikan laba bersih akan menarik investor untuk berinvestasi yang bisa berdampak naiknya harga saham. Kemudian untuk debt to equity ratio masing-masing bank mengalami fluktuasi setiap tahunnya. Perusahaan yang bergerak dalam bidang keuangan seperti bank, perusahaan asuransi dan perusahaan investasi cenderung memiliki DER yang tinggi, karena sebagian besar dana yang dikelolanya adalah dana pihak ketiga, dalam hal ini dana pihak ketiga secara akuntansi dianggap sebagai liabilities atau hutang. Untuk jenis perusahaan seperti ini semakin besar modal pihak ketiga yang perusahaan kelola maka kemungkinan untuk mendapat laba juga semakin tinggi. Dari tabel tersebut dapat dilihat pada Bank Mandiri terdapat penurunan DER dari tahun 2013 ke 2014 tetapi harga sahamnya malah mengalami kenaikan. Selanjutnya dapat dilihat pada arus kas operasi di masing-masing bank terdapat kenaikan dan penurunan dalam setiap tahunnya, di tahun 2015 Bank BTN mengalami penurunan arus kas operasi dari tahun 2014 tetapi harga sahamnya malah naik, kemudian di tahun 2014 Bank BNI mengalami kenaikan arus kas perusahaan tetapi harga sahamnya malah mengalami penurunan. Padahal titik awal yang baik dalam pemeriksaan laporan keuangan adalah menemukan kas bersih yang disediakan oleh aktivitas operasi yang tinggi, maka hal ini mengindikasikan bahwa perusahaan mampu menghasilkan kas yang mencukupi secara internal dari operasi untuk membayar kewajibannya tanpa harus meminjam dari luar yang seharusnya berdampak pada naiknya kepercayaan investor dan berimbas pada kenaikan harga saham.

Penelitian tentang pengaruh laba bersih, DER dan arus kas operasi telah banyak dilakukan tetapi memiliki hasil yang berbedabeda. Penelitian yang menyatakan terdapat pengaruh yang signifikan antara laba bersih dan arus kas operasi diantaranya adalah hasil penelitian Irma samosir (2014), sedangkan penelitian yang menyatakan tidak ada pengaruh antara laba bersih dan arus kas operasi adalah hasil penelitian yang dilakukan dilakukan Agus prana sugata, Ervita safitri dan Kardinal (2014). Kemudian penelitian yang dilakukan oleh Euis masopah (2012) menunjukkan hasil bahwa Debt to equity ratio memiliki pengaruh yang positif tidak signifikan terhadap harga saham. Sedangkan dilain pihak penelitian yang dilakukan oleh Aghnia (2014) menunjukkan hasil bahwa Debt to equity ratio tidak berpengaruh terhadap harga saham.

Beberapa bukti tersebut menunjukkan bahwa ada research gap dalam penelitianpenelitian terdahulu tentang pengaruh laba bersih, DER dan arus kas operasi terhadap harga saham. Sebagian peneliti menemukan bahwa terdapat pengaruh yang positif signifikan antara laba bersih, DER dan arus kas operasi terhadap harga saham tetapi sebagian lagi tidak menemukan adanya pengaruh antara laba bersih, DER dan arus kas operasi terhadap harga saham. Penelitianpenelitian terdahulu masih menghasilkan kesimpulan yang berbeda-beda, sehingga penulis tertarik untuk mengkaji ulang tentang pengaruh laba bersih, DER dan arus kas operasi terhadap harga saham. Adapun persamaan penelitian ini dengan penelitian terdahulu adalah sama-sama menggunakan variabel laba bersih, DER dan arus kas operasi. Sedangkan perbedaannya dalam penelitian ini peneliti mengambil sampel dari 4 bank BUMN yang terdaftar di Bursa Efek Indonesia periode 2009-2016. Selain itu 
variabel harga saham yang digunakan dalam penelitian ini adalah harga saham rata-rata yang dihitung berdasarkan periode sepuluh hari sebelum laporan keuangan dipublikasikan, pada saat hari publikasi laporan keuangan dan rata-rata harga saham sepuluh hari sesudah laporan keuangan dipublikasikan. Sepuluh hari sebelum dan sepuluh hari sesudah laporan keuangan dipublikasikan dipilih oleh peneliti karena dianggap jumlah hari yang mampu mencerminkan reaksi pasar.

Berdasarkan data yang ada dapat dilihat bahwa walaupun terjadi kenaikan laba bersih setiap tahunnya tetapi tidak diiringi dengan kenaikan harga saham hal ini memperjelas bahwa investor tidak menghiraukan informasi tersebut, adanya kenaikan laba bersih disertai dengan kenaikan arus kas operasi yang mencukupi untuk membiayai kegiatan operasional perusahaan sehari-hari tetapi tidak diiringi dengan kenaikan harga saham,yang terjadi malah harga sahamnya menurun dan dapat dilihat semakin tinggi DER yang di bentuk oleh bank tersebut seharusnya menunjukkan kemampuan perusahaan mengelola dana pihak ketiga semakin besar. Untuk jenis perusahaan seperti ini semakin besar modal pihak ketiga yang perusahaan kelola maka kemungkinan untuk mendapat laba juga semakin tinggi tetapi tidak diiringi dengan kenaikan harga saham.

\section{TELAAH TEORI DAN PENGEMBANGAN HIPOTESIS}

2.1 Hubungan Laba Bersih Dengan Harga Saham

Suatu perusahaan dikatakan berhasil apabila mampu memaksimumkan nilai perusahaan yang salah satunya dapat dicapai dengan meningkatkan laba bersih perusahaan. Laba bersih merupakan kelebihan pendapatan yang dikeluarkan dalam proses menghasilkan pendapatan. Tujuan perusahaan dalam suatu perekonomian yang bersaing adalah untuk memperoleh laba yang sebesar-besarnya sesuai dengan pertumbuhan perusahaan dalam jangka panjang. Walaupun tidak semua dalam organisasi perusahaan menjadikan laba sebagai tujuan utama.

Laba bersih sebuah perusahaan sering dijadikan sebagai sebuah patokan maupun ukuran keberhasilan kinerja dalam sebuah perusahaan. Dapat diasumsikan bahwa semakin besar laba bersih yang dapat dicapai maka semakin berhasil pula kinerja perusahaan yang bersangkutan. Hal ini tentu saja akan menjadi informasi yang penting bagi investor karena informasi laba ini akan memberikan perkiraan return yang akan diperoleh sehingga akan berimbas pada pergerakan harga saham karena terjadi pergerakan permintaan dan penawaran saham.

Menurut simamora (2012: 246) menyatakan bahwa laba yang meningkat dari waktu ke waktu membuat investor tertarik dengan saham perusahaan dengan begitu harga saham meningkat. Laba yang tinggi akan mendorong investor untuk membeli saham perusahaan yang bersangkutan karena tertarik akan laba investasi yang lebih tinggi, ini secara langsung akan mendorong pada peningkatan harga saham dan return saham perusahaan.

Kemampuan perusahaan dalam menghasilkan laba menunjukkan eksistensi peusahaan tersebut. Semakin tinggi laba yang dicapai perusahaan maka orang-orang cenderung percaya bahwa perusahaan itu mampu bertahan ditengah-tengah persaingan, keadaan ini akan menarik investor untuk memiliki saham tersebut. Sebaliknya perusahaan yang tidak mampu mencapai laba yang tinggi menunujukkan bahwa rentabilitas perusahaan rendah sehingga mempengaruhi keinginan investor untuk menanamkan modalnya diperusahaan tersebut.

Informasi akuntansi berupa laporan keuangan dianalisis oleh investor yaitu informasi laba. Laba akan sangat mempengaruhi investor dalam mengambil keputusan investasi. $\mathbf{H 1}=$ Laba bersih 


\section{berpengaruh terhadap harga saham}

\subsection{Hubungan Debt to Equity Ratio dengan Harga Saham}

Debt to equity ratio akan mempengaruhi harga saham karena rasio ini digunakan untuk mengukur kemampuan perusahaan dalam menutupi sebagian atau seluruh hutang baik jangka pendek maupun jangka panjang dengan dana yang berasal dari modal sendiri maupun modal asing. Dengan kata lain rasio ini mengukur seberapa besar total passiva yang terdiri atas persentase modal perusahaan sendiri dibandingkan dengan hutang. Jadi apabila dalam laporan keuangan perusahaan, perusahaan dapat memenuhi kewajibannya maka aktifitas perusahaan akan berjalan dengan baik, sehingga harga saham pun cenderung meningkat.

Debt to equity ratio merupakan rasio solvabilitas yang mengukur kemampuan kinerja perusahaan dalam mengembalikan hutang jangka pendek maupun jangka panjangnya dengan melihat perbandingan antara total hutang dengan total ekuitasnya. Debt to equity ratio memberikan jaminan tentang seberapa hutang perusahaan yang dijamin dengan modal perusahaan sendiri yang digunakan sebagai sumber pendanaan usaha. Rasio ini menunjukkan komposisi atau struktur modal dari total pinjaman (hutang) terhadap total hutang jangka pendek maupun jangka panjang semakin besar dibanding dengan total modal sendiri sehingga berdampak semakin besar beban perusahaan terhadap pihak luar atau kreditur.

Menurut Husnan (2003:303) menyatakan bahwa tinggi rendahnya rasio hutang pada modal (DER) secara tidak langsung dapat mempengaruhi harga saham dimasa yang akan datang. Debt to equity ratio merupakan rasio hutang yang diukur dari perbandingan utang dan ekuitas (modal sendiri), semakin tinggi rasio hutang terhadap modal berarti modal sendiri semakin sedikit dibanding hutangnya. Semakin kecil rasio hutang terhadap modal semakin baik bagi perusahaan dan akan meningkatkan harga saham. $\mathbf{H} 2=$ Debt to equity ratio berpengaruh terhadap harga saham

\subsection{Hubungan Arus Kas Operasi Dengan Harga Saham}

Selain informasi mengenai kemampuan perusahaan memperoleh laba, informasi kinerja keuangan perusahaan yang diperkirakan dapat mempengaruhi harga pasar saham adalah informasi mengenai arus kas.

Tendelilin (2010:324) menjelaskan kaitan antara arus kas terhadap harga saham, sebagai berikut:

"Data aliran kas perusahaan bisa memberikan pemahaman yang lebih mendalam bagi investor tentang perubahan harga saham yang akan terjadi".

Pelaporan arus kas dari aktivitas operasi berisi informasi yang menentukan apakah dari operasi perusahaan dapat menghasilkan arus kas yang cukup untuk melunasi pinjaman, memelihara kemampuan operasi perusahaan, membayar deviden dan melakukan investasi baru tanpa mengandalkan sumber dana dari luar. Nilai arus kas yang berasal dari aktivitas operasi dapat mencerminkan bagaimana operasi perusahaan berjalan serta akan dapat menghasilkan arus kas yang cukup untuk melunasi kewajibannya, mempertahankan kemampuan operasi, membayar deviden tunai dan melakukan investasi baru tanpa mengandalkan sumber dana dari luar. $\mathbf{H 3}=$ Arus kas operasi berpengaruh terhadap harga saham

2.4 Laba Bersih, Debt to equity ratio dan Arus kas operasi secara bersama-sama berpengaruh terhadap harga saham

H4 = Laba Bersih, Debt to equity ratio dan Arus kas operasi secara bersamasama berpengaruh terhadap harga saham 


\section{METODE PENELITIAN}

Metode yang digunakan dalam penelitian ini adalah metode deskriptif dan verifikatif (inferensial). Metode deskriptif yaitu suatu metode yang digunakan dalam meneliti suatu kelompok manusia,suatu objek, suatu set kondisi, suatu sistem pemikiran ataupun suatu kelas peristiwa pada masa sekarang. Tujuan penelitian deskriptif ini adalah untuk membuat suatu gambaran, deskripsi atau lukisan secara sistematis,faktual dan akurat mengenai fakta-fakta, sifat-sifat serta hubungan antara fenomena yang akan diselidiki.

Sedangkan metode verifikatif (inferensial) merupakan metode yang digunakan untuk melakukan perkiraan dan pengajuan hipotesis. Metode ini digunakan untuk menjawab permasalahan mengenai hubungan antara laba bersih, DER dan arus kas operasi sebagai variabel independen serta harga saham sebagai variabel dependen.

Dalam penelitian ini data diperoleh dari laporan keuangan perusahaan yang telah dipublikasikan (data sekunder) yang kemudian diolah sesuai dengan permasalahan yang akan diteliti,selanjutnya dilakukan analisis regresi dan korelasi karena penelitian ini menggunakan tiga variabel independen dan satu variabel dependen. Analisis ini digunakan untuk mengetahui sejauh mana adanya hubungan variabel independen dan dependen. Sedangkan analisis korelasi digunakan untuk menerangkan kekuatan dan arah hubungan antara variabel independen dan dependen

Dalam penelitian ini, metode deskriptif verifikatif tersebut digunakan untuk menguji lebih dalam pengaruh laba bersih, debt to equity ratio dan arus kas operasi terhadap harga saham pada bank BUMN yang terdaftar di Bursa Efek Indonesia periode 2009-2016 serta menguji teori dengan pengujian suatu hipotesis apakah diterima atau ditolak. Kemudian penelitian ini menggunakan pendekatan kuantitatif karena memerlukan perhitungan yang bersifat sistematis yang menitikberatkan pada pengujian hipotesis. Event window yang digunakan dalam penelitian ini adalah 21 hari yang terdiri atas 10 hari sebelum publikasi laporan keuangan, hari pada saat publikasi laporan keuangan dan 10 hari setelah publikasi laporan keuangan.

Regresi data panel untuk melihat pengaruh antara variabel independen yang terdiri dari laba bersih, DER dan arus kas operasi terhadap harga saham. Untuk membantu penelitian, penulis menggunakan program Eviews 8.0 untuk pengolahan data penelitian.

Model regresi data panel penelitian ini adalah :

$$
Y_{i t}=\alpha_{i t}+\beta_{1} X_{1 i t}+\beta_{2} X_{2 i t}+\beta_{3} X_{3 i t}
$$

Keterangan :

Y : Harga Saham

$\alpha$ : Konstanta

$\beta$ : Koefisien regresi untuk variabel independen

$\mathrm{X}_{1}$ : Laba Bersih

$\mathrm{X}_{2}$ : Debt to Equity Ratio

$\mathrm{X}_{3}$ : Arus Kas Operasi

Pengujian hipotesis ini dibagi kedalam dua jenis pengujian, yaitu pengujian secara simultan yang disebut uji f (f-test) dan pengujian secara parsial yang disebut uji $t(t-$ test).

\section{Uji Signifikansi Simultan (Uji Statistik f)}

Uji statistik $f$ digunakan untuk mengetahui apakah semua variabel independen yang dimasukkan dalam model regresi memiliki pengaruh secara simultan terhadap variabel dependen. Langkahlangkah pengujian dengan menggunakan uji $\mathrm{f}$ adalah sebagai berikut:

\section{Menentukan tingkat signifikansi}

Tingkat signifikansi adalah standar statistik yang digunakan untuk menolak $\mathrm{H}_{0}$. Jika ditentukan tingkat signifikansi 5\% ( $\alpha=$ $0,05), \mathrm{H}_{0}$ ditolak hanya jika hasil perhitungan dari sampel sedemikian berbeda dengan nilai dugaan (yang dihipotesakan). 


\section{Merumuskan Hipotesis}

Hipotesis yang akan diuji dalam penelitian ini berkaitan dengan ada atau tidaknya pengaruh secara simultan variabel independen terhadap variabel dependen. Dimana hipotesis nol $\left(\mathrm{H}_{0}\right)$ yaitu hipotesis yang menyatakan tidak ada pengaruh diantara parameter dan data statistik yang dibandingkan, umumnya diformulasikan untuk ditolak.

Sedangkan hipotesis alternatif $\left(\mathrm{H}_{\mathrm{a}}\right)$ merupakan pernyataan yang sebaliknya dari rumusan yang dinyatakan hipotesis nol, hipotesis alternatif merupakan hipotesis yang diajukan peneliti dalam penelitian ini. Masingmasing hipotesis tersebut dijelaskan sebagai berikut:

$$
\mathrm{H}_{0}: \boldsymbol{\beta}_{1}=\boldsymbol{\beta}_{2}=\boldsymbol{\beta}_{3}=\mathbf{0}
$$

artinya tidak ada pengaruh signifikan secara simultan antara variabel independen, yaitu Laba bersih (X1), debt to equity ratio (X2), dan Arus kas operasi (X3) terhadap variabel dependen, yakni harga saham $(Y)$.

\section{$\mathrm{H}_{\mathrm{a}}: \boldsymbol{\beta}_{1} \neq \boldsymbol{\beta}_{\mathbf{2}} \neq \boldsymbol{\beta}_{3} \neq 0$}

artinya terdapat pengaruh signifikan secara simultan antara variabel independen, yaitu Laba bersih (X1), debt to equity ratio (X2), dan Arus kas operasi (X3) terhadap variabel dependen, yakni harga saham $(Y)$

Menghitung Uji $\mathrm{f}$ (f-test)

Keterangan:

$$
f=\frac{R^{2} /(k-1)}{\left(1-R^{2}\right) /(n-k)}
$$

$$
\begin{array}{lll}
\mathrm{R}^{2} & : & \text { koefisien determinasi gabungan } \\
\mathrm{k} & : & \text { jumlah variabel independen } \\
\mathrm{n} & : & \text { jumlah sampel }
\end{array}
$$

\section{Kriteria Pengambilan Keputusan}

$\mathrm{H}_{0}$ ditolak jika $p$-value $\mathrm{f}$ statistik $<0,05$ atau $f_{\text {hitung }}>f_{\text {tabel }}$

$\mathrm{H}_{0}$ diterima jika $p$-value f statistik $>0,05$

atau $\mathrm{f}_{\text {hitung }}<\mathrm{f}_{\text {tabel }}$

\section{Uji Signifikansi Parsial (Uji Statistik t)}

Uji statsitik $t$ pada dasarnya digunakan untuk mengetahui seberapa jauh pengaruh variabel independen secara individual dalam menerangkan variasi variabel independen. Langkah-langkah pengujian hipotesis secara parsial adalah sebagai berikut:

\section{Menentukan Tingkat Signifikansi}

Tingkat signifikansi $0.05 \%$ atau $5 \%$ artinya kemungkinan besar hasil penarikan kesimpulan memiliki probabilitas 95\% atau korelasi kesalahan sebesar $5 \%$.

\section{Merumuskan Hipotesis}

Hipotesis yang akan diuji dalam penelitian ini berkaitan dengan ada atau tidaknya pengaruh antara variabel $x$ (variabel bebas) dengan variabel y (variabel terikat). Dimana hipotesis nol $\left(\mathrm{H}_{0}\right)$ yaitu hipotesis $\mathrm{C}$ tentang tidak adanya pengaruh. Sedangkan hipotesis alternatif $\left(\mathrm{H}_{\mathrm{a}}\right)$ merupakan hipotesis yang diajukan peneliti dalam penelitian ini. Masing-masing hipotesis tersebut dijelaskan sebagai berikut:

$$
\mathrm{H}_{01}: \boldsymbol{\beta}_{1}=\mathbf{0}
$$

artinya tidak terdapat pengaruh antara laba bersih terhadap harga saham

$$
\mathrm{H}_{\mathrm{a} 1}: \boldsymbol{\beta}_{1} \neq \mathbf{0}
$$

artinya terdapat pengaruh antara laba bersih terhadap harga saham

$$
\mathrm{H}_{02}: \boldsymbol{\beta}_{2}=\mathbf{0}
$$

artinya tidak terdapat pengaruh antara debt to equity ratio terhadap harga saham.

$$
\mathrm{H}_{\mathrm{a} 2}: \boldsymbol{\beta}_{\mathbf{2}} \neq \mathbf{0}
$$

artinya terdapat pengaruh antara debt to equity ratio terhadap harga saham

$$
\mathrm{H}_{03}: \boldsymbol{\beta}_{3}=\mathbf{0}
$$

artinya tidak terdapat pengaruh antara arus kas operasi terhadap harga saham 
$\mathbf{H}_{\mathrm{a} 3}: \boldsymbol{\beta}_{3} \neq \mathbf{0}$

artinya terdapat pengaruh antara arus kas operasi terhadap harga saham

\section{Menghitung Uji t (t-test)}

Keterangan :

$$
t_{\text {hitung }}=\frac{b_{i}}{S b_{i}}
$$

$b_{i}:$ koefisien regresi

$\mathrm{Sb}_{\mathrm{i}}$ : standar deviasi koefisien regresi

Kriteria Pengambilan Keputusan

$\mathrm{H}_{0}$ ditolak jika p-value $<0,05$ atau $t_{\text {hitung }}>t_{\text {tabel }}$
$\mathrm{H}_{0}$ diterima jika $\mathrm{p}$-value $>0,05$ atau $\mathrm{t}_{\text {hitung }}<\mathrm{t}_{\text {tabel }}$

\section{HASIL DAN PEMBAHASAN \\ 4.1 Statistik Deskriptif}

Statistik deskriptif memberikan gambaran atau deskripsi data yang dilihat dari nilai rata-rata, maksimum dan minimum. Variabel dependen pada penelitian ini adalah Harga saham dengan variabel independennya yaitu Laba bersih, Debt to Equity Ratio dan Arus Kas Operasi.

Statistik Deskriptif Per Indikator Minimum dan Maximum Values

\begin{tabular}{|c|c|c|c|c|}
\hline & Laba Bersih & DER & $\begin{array}{c}\text { Arus Kas } \\
\text { Operasi }\end{array}$ & $\begin{array}{c}\text { Harga } \\
\text { Saham }\end{array}$ \\
\hline Minimum & 490.453 & 5,26 & -24.097 .325 & 1.029 \\
\hline Maximum & 26.227 .991 & 11,80 & 75.822 .636 & 11.800 \\
\hline Rataan & 1.409 .060 & 6,79 & 1.928 .147 & $1,312.75$ \\
\hline Median & 16.341 .795 & 10,64 & 24.340 .130 & $8,415.50$ \\
\hline
\end{tabular}

Nilai minimum dan maximum dari masing-masing variabel yang di teliti. Dapat dilihat perolehan laba bersih terendah berada di 490.453 dan tertinggi berada di 26.227.991. Debt to Equity Ratio memiliki nilai minimum pada 5,26 dan nilai tertinggi pada 11,80 . Arus kas operasi memiliki nilai terendah pada 24.097.325 dan nilai tertinggi pada 75.822.636. Harga saham memiliki nilai terendah pada 1.029 dan nilai tertinggi 11.800 .

Nilai rata-rata dan nilai tengah (median) dari masing-masing variabel yang di teliti. Dapat dilihat untuk laba bersih nilai rata-rata sebesar 1.409.060 dan nilai tengah sebesar 16.341.795. Kemudian untuk Debt to Equity Ratio nilai rata-rata sebesar 6,79 dan nilai tengah sebesar 10,64. Selanjutnya untuk Arus kas operasi nilai rata-rata sebesar 1.928.147 dan nilai tengah sebesar 24.340.130. Untuk Harga saham nilai rata-rata sebesar $1,312.75$ dan nilai tengah sebesar 8,415.50.

\subsection{Analisis Laba bersih}

Laba bersih terbentuk dari selisih laba operasi dengan beban bunga yang hasilnya akan dikurangi pajak penghasilan.

Diantara keempat bank BUMN yang menjadi sampel penelitian, Bank Rakyat Indonesia memperoleh laba bersih yang paling tinggi dan selalu naik setiap tahunnya. Kenaikan laba bersih Bank Rakyat Indonesia paling tinggi terjadi tahun 2010, yaitu naik sebesar 4.250.459 milliar rupiah. Laba bersih Bank Negara Indonesia selalu mengalami kenaikan hingga tahun 2014, namun pada tahun 2015 sempat mengalami penurunan yang disebabkan tingginya pembentukan cadangan kerugian penurunan nilai pada tahun 2015. Laba bersih Bank Mandiri juga terus mengalami kenaikan hingga tahun 2015, namun pada tahun 2016 mengalami penurunan yang sangat tajam, juga disebabkan tingginya pembentukan cadangan kerugian penurunan nilai pada tahun 2016. Bank Tabungan Negara memiliki laba bersih paling kecil diantara keempat bank tersebut, dan 
cenderung berfluktuasi selama periode tahun 2009-2016.

Pada tabel 4.1 dapat dilihat dilihat laba bersih yang diperoleh keempat perusahaan BUMN sektor perbankan di Bursa Efek Indonesia cenderung naik tiap tahunnya selama periode tahun 2009-2016.

\subsection{Analisis Rasio Hutang Atas Modal}

Rasio Hutang Atas Modal mengukur tingkat penggunaan hutang oleh perusahaan berdasarkan modal yang dimiliki. Semakin besar rasio DER menunjukkan semakin besar tingkat ketergantungan perusahaan terhadap pihak eksternal (kreditur) dan semakin besar pula beban biaya hutang (biaya bunga) yang harus dibayar oleh perusahaan. Berikut gambaran data debt to equty ratio perusahaan BUMN sektor perbankan di Bursa Efek Indonesia selama periode tahun 2009-2016.

Dapat dilihat diantara keempat bank BUMN, Bank Tabungan Negara memiliki debt to equity ratio paling tinggi, dengan rata-rata mencapai 10,64 kali setiap tahunnya. Sebaliknya Bank Negara Indonesia memiliki debt to equity ratio paling rendah, dengan ratarata 6,79 kali setiap tahunnya. Perusahaan biasanya memiliki debt to equity ratio yang tinggi karena dana simpanan nasabah berupa tabungan, giro dan deposito masuk kedalam pos hutang.

\subsection{Analisis Arus Kas Operasi}

Arus kas operasi adalah aliran kas dari kegiatan operasi yaitu aliran kas bersih (masuk dan keluar) yang berkaitan dengan kegiatan yang meliputi semua transaksi dan kejadian yang bukan termasuk dalam kegiatan investasi dan pendanaan. Kegiatan operasi biasanya melibatkan produksi, pengiriman barang dan penyerahan jasa. Aliran kas dari kegiatan operasi biasanya memberikan pengaruh terhadap kas transaksi dan kejadian lain yang dimasukkan dalam penentuan laba.

Dapat dilihat diantara keempat bank BUMN, Bank Tabungan Negara memiliki debt to equity ratio paling tinggi, dengan rata-rata mencapai 10,64 kali setiap tahunnya. Sebaliknya Bank Negara Indonesia memiliki debt to equity ratio paling rendah, dengan ratarata 6,79 kali setiap tahunnya. Perusahaan biasanya memiliki debt to equity ratio yang tinggi karena dana simpanan nasabah berupa tabungan, giro dan deposito masuk kedalam pos hutang.

\subsection{Pengaruh Laba bersih Terhadap Harga saham}

\section{Fixed Effect Model}

\begin{tabular}{crrrr} 
Variable & Coefficient & Std. Error & t-Statistic & Prob. \\
\hline \hline EAT? & 0.000307 & $4.97 \mathrm{E}-05$ & 6.168616 & 0.0000 \\
DER? & -329.6267 & 142.5829 & -2.311825 & 0.0293 \\
AKO? & $2.57 \mathrm{E}-05$ & $9.26 \mathrm{E}-06$ & 2.773027 & 0.0103 \\
C & 4624.600 & 1614.156 & 2.865026 & 0.0083 \\
Fixed Effects (Cross) & & & \\
BNI--C & -563.0627 & & \\
MANDIRI--C & 1127.809 & & \\
BRI--C & -238.6191 & & \\
BTN--C & -326.1275 & & \\
\hline \hline
\end{tabular}

Effects Specification

Cross-section fixed (dummy variables) 
R-squared

Adjusted R-squared

S.E. of regression

Sum squared resid

Log likelihood

F-statistic

Prob(F-statistic)
0.967592 Mean dependent var

0.959814 S.D. dependent var

717.8149 Akaike info criterion

12881454 Schwarz criterion

-251.8950 Hannan-Quinn criter.

124.4029 Durbin-Watson stat
5608.469

3580.769

16.18094

16.50157

16.28722

2.823130

Keterangan :

Berdasarkan uji Chow dan uji Hausman, model terbaik untuk digunakan adalah FEM

Nilai R squared $=0,968$ dari table diatas menunjukkan bahwa 96,8\% dari varians harga saham dapat dijelaskan oleh perubahan dalam variable EAT, DER dan AKO. Sisanya 3,3 \% diterangkan oleh faktor lain diluar model

Hipotesis pertama yang akan diuji adalah pengaruh laba bersih terhadap harga saham. Untuk membuktikan apakah laba bersih berpengaruh terhadap harga saham dilakukan pengujian dengan hipotesis statistik sebagai berikut.

\section{Ho. $\beta_{1}=0$ : Laba bersih secara parsial tidak berpengaruh terhadap harga saham pada perusahaan BUMN sektor perbankan di Bursa Efek Indonesia}

Ha. $\beta_{1} \neq 0$ : Laba bersih secara parsial berpengaruh terhadap harga saham pada perusahaan BUMN sektor perbankan di Bursa Efek Indonesia.

Dasar Pengambilan Keputusan :

Jika probabilitasnya (nilai sig) $>0.005$ atau $-\mathrm{t}$ table $<\mathrm{t}$ hitung $<\mathrm{t}$ tabel maka $\mathrm{H} 0$ tidak ditolak.

Jika probabilitasnya (nilai sig) $<0.005$ atau $\mathrm{t}$ hitung $<-\mathrm{t}$ tabel atau $\mathrm{t}$ hitung $>\mathrm{t}$ table maka $\mathrm{H} 0$ ditolak.

Ringkasan hasil pengujian yang digunakan untuk menguji pengaruh laba bersih terhadap harga saham dapat dilihat pada tabel. Pada tabel dapat dilihat nilai sig variable EAT $=$ $0.000<0.05$, lalu nilai thitung variabel laba bersih sebesar 6.16 lebih besar dari $t_{\text {tabel }} 2.064$, sehingga pada tingkat kekeliruan 5\% diputuskan untuk menolak Ho sehingga $\mathrm{Ha}$ diterima. Dengan demikian dapat disimpulkan bahwa laba bersih secara parsial berpengaruh positif dan signifikan terhadap harga saham pada perusahaan BUMN sektor perbankan di Bursa Efek Indonesia. Hasil penelitian ini memberikan bukti empiris bahwa semakin besar laba bersih yang diperoleh perusahaan cenderung akan menaikkan harga saham perusahaan tersebut. Begitu juga sebaliknya jika laba bersih mengalami penurunan, maka harga saham juga akan menurun. Informasi laba bersih yang terdapat dalam laporan laba rugi yang dapat menunjukkan seberapa baik kinerja suatu perusahaan dan menunjukkan kemampuan perusahaan dalam memberikan pengembalian atas investasi yang dilakukan oleh investor. Hal ini akan menyebabkan permintaan terhadap saham perusahaan tersebut meningkat dan harga saham juga meningkat. Begitu pula sebaliknya, jika laba bersih menurun, permintaan terhadap saham tersebut juga akan menurun, kemudian akan berdampak pula pada harga saham yang menurun.

\subsection{Pengaruh Debt to equity ratio Terhadap Harga saham}

Hipotesis kedua yang akan diuji adalah pengaruh debt to equity ratio terhadap harga saham. Untuk membuktikan apakah debt to equity ratio berpengaruh terhadap harga saham 
dilakukan pengujian dengan hipotesis statistik sebagai berikut.

$\begin{array}{ll}\text { Ho. } \beta_{2}=0: & \begin{array}{l}\text { Debt to equity ratio secara parsial tidak berpengaruh terhadap harga } \\ \text { saham pada perusahaan BUMN sektor perbankan di Bursa Efek } \\ \text { Indonesia }\end{array} \\ \text { Ha. } \beta_{2} \neq 0: & \begin{array}{l}\text { Debt to equity ratio secara parsial berpengaruh terhadap harga } \\ \text { saham pada perusahaan BUMN sektor perbankan di Bursa Efek } \\ \text { Indonesia }\end{array}\end{array}$

Dasar Pengambilan Keputusan :

Jika probabilitasnya (nilai sig) $>0.005$ atau $-\mathrm{t}$ table $<\mathrm{t}$ hitung $<\mathrm{t}$ tabel maka $\mathrm{H} 0$ tidak ditolak.

Jika probabilitasnya (nilai sig) $<0.005$ atau $\mathrm{t}$ hitung $<-\mathrm{t}$ tabel atau $\mathrm{t}$ hitung $>\mathrm{t}$ table maka $\mathrm{H} 0$ ditolak.

Ringkasan hasil pengujian yang digunakan untuk menguji pengaruh debt to equity ratio terhadap harga saham dapat dilihat pada tabel 4.17 berikut :

Pada tabel dapat dilihat nilai sig variable $\mathrm{DER}=0.0293<0.05$, lalu $\mathrm{t}_{\text {hitung }}$ variabel DER sebesar $-2,311$ lebih kecil dari negatif $t_{\text {tabel }}$ $(-2,064)$ maka pada tingkat kekeliruan 5\% diputuskan untuk menolak Ho sehingga $\mathrm{Ha}$ diterima. Dengan demikian dapat disimpulkan bahwa debt to equity ratio secara parsial berpengaruh negative dan signifikan terhadap harga saham pada perusahaan BUMN sektor perbankan di Bursa Efek Indonesia. Hasil penelitian ini memberikan bukti empiris bahwa semakin tinggi nilai debt to equity ratio perusahaan cenderung akan menurunkan harga saham perusahaan tersebut. Tinggi rendahnya debt to equity ratio merupakan faktor yang mempengaruhi minat investor untuk menanamkan modalnya. Tinggi atau rendahnya hutang mempengaruhi minat investor untuk menanamkan sahamnya, karena investor melihat dari seberapa besar perusahaan mampu memanfaatkan hutangnya untuk biaya operasional perusahaan tersebut, jika perusahaan berhasil memanfaatkan hutang untuk biaya operasional maka akan memberikan sinyal positif bagi investor untuk menanamkan modalnya pada perusahaan tersebut dan harga saham akan naik, sebaliknya jika perusahaan gagal dalam memanfaatkan hutangnya akan memberikan sinyal negatif bagi investor.

\subsection{Pengaruh Arus Kas Operasi Terhadap Harga saham}

Hipotesis ketiga yang akan diuji adalah pengaruh arus kas operasi terhadap harga saham. Untuk membuktikan apakah arus kas operasi berpengaruh terhadap harga saham dilakukan pengujian dengan hipotesis statistik sebagai berikut.

Ho. $\beta_{3}=0$ : Arus kas operasi tidak berpengaruh terhadap harga saham pada perusahaan BUMN sektor perbankan di Bursa Efek Indonesia

Ha. $\beta_{3} \neq 0$ : Arus kas operasi berpengaruh terhadap harga saham pada perusahaan BUMN sektor perbankan di Bursa Efek Indonesia 
Dasar Pengambilan Keputusan :

Jika probabilitasnya (nilai sig) $>0.005$ atau $-\mathrm{t}$ table $<\mathrm{t}$ hitung $<\mathrm{t}$ tabel maka H0 tidak ditolak.

Jika probabilitasnya (nilai sig) $<0.005$ atau $t$ hitung <-t tabel atau $\mathrm{t}$ hitung $>\mathrm{t}$ table maka $\mathrm{H} 0$ ditolak.

Ringkasan hasil pengujian yang digunakan untuk menguji pengaruh arus kas operasi terhadap harga saham dapat dilihat pada tabel berikut :

Pada tabel dapat dilihat nilai sig variable $\mathrm{AKO}=0.0103<0.05$, lalu nilai $t_{\text {hitung }}$ variabel arus kas operasi sebesar 2,773 lebih besar dari $t_{\text {tabel }}$ 2,064 maka pada tingkat kekeliruan 5\% diputuskan untuk menolak Ho sehingga $\mathrm{Ha}$ diterima. Dengan demikian dapat disimpulkan bahwa arus kas operasi secara parsial berpengaruh positif dan signifikan terhadap harga saham perusahaan BUMN sektor perbankan di Bursa Efek Indonesia. Hasil penelitian ini memberikan bukti empiris bahwa semakin besar arus kas perusahaan dari aktivitas operasi cenderung akan menaikkan harga saham perusahaan tersebut. Arus kas yang berasal dari aktivitas operasi merupakan indikator utama untuk menentukan apakah operasi entitas dapat menghasilkan arus kas yang cukup untuk melunasi pinjaman, memelihara kemampuan operasi entitas, membayar deviden dan melakukan investasi baru tanpa mengandalkan sumber pendanaan dari luar.

\subsection{Pengaruh Laba Bersih Terhadap Harga Saham}

Berdasarkan uji hipotesis yang menyatakan bahwa laba bersih berpengaruh signifikan terhadap harga saham. Hal ini menunjukkan teori yang diutarakan Simamora (2012) dimana laba yang meningkat dari waktu ke waktu membuat investor tertarik dengan saham perusahaan dengan begitu harga saham meningkat. Laba yang tinggi akan mendorong investor untuk membeli saham perusahaan yang bersangkutan karena tertarik akan laba investasi yang lebih tinggi, ini secara langsung akan mendorong pada peningkatan harga saham dan return saham perusahaan.

Berdasarkan hasil pengolahan data diperoleh nilai $t_{\text {hitung }}$ variabel laba bersih sebesar 6,168616 dengan nilai probabilitas mendekati nol. Karena nilai $t_{\text {statistic }} 6,168616$ lebih besar dari $t_{\text {statistic }} 2,064$ sehingga pada tingkat kekeliruan 5\% diputuskan untuk menolak Ho sehingga Ha diterima. Dengan demikian dapat disimpulkan bahwa laba bersih secara parsial berpengaruh positif dan signifikan terhadap harga saham pada perusahaan BUMN sektor perbankan di Bursa Efek Indonesia. Hasil penelitian ini memberikan bukti empiris bahwa semakin besar laba bersih yang diperoleh perusahaan cenderung akan menaikkan harga saham perusahaan tersebut, demikian pula sebaliknya.

\subsection{Pengaruh Rasio Hutang Atas Modal Terhadap Harga Saham}

Berdasarkan uji hipotesis yang menyatakan bahwa Debt to Equity Ratio berpengaruh signifikan terhadap harga saham. Hal ini menunjukkan teori yang diutarakan Husnan (2003:303) menyatakan bahwa tinggi rendahnya rasio hutang pada modal (DER) secara tidak langsung dapat mempengaruhi harga saham dimasa yang akan datang. Debt to equity ratio merupakan rasio hutang yang diukur dari perbandingan utang dan ekuitas (modal sendiri), semakin tinggi rasio hutang terhadap modal berarti modal sendiri semakin sedikit dibanding hutangnya. Semakin kecil rasio hutang terhadap modal semakin baik bagi perusahaan dan akan meningkatkan harga saham.

Hasil penelitian ini juga selaras dengan hasil penelitian yang dilakukan oleh Euis Masopah (2012) dan Ema Novasari (2013). Namun penelitian yang dilakukan Aghnia Nur Hadzmi (2014) dalam "Pengaruh Price Earning Ratio dan Debt to Equity Ratio Terhadap Harga Saham (Studi Kasus pada Perusahaan yang Tergabung dalam Group Astra" yang melihat hubungan Debt to Equity Ratio dengan harga saham menunjukkan hasil yang negatif. 
Berdasarkan hasil pengolahan data diperoleh nilai $t_{\text {statistic }}$ variabel debt to equity ratio sebesar -2,311825 dengan nilai probabilitas 0,0293 . Karena nilai $t_{\text {statistic }}-2,311825$ lebih kecil dari negatif $t_{\text {tabel }}-2,064$ maka pada tingkat kekeliruan 5\% diputuskan untuk menolak Ho sehingga Ha diterima. Dengan demikian dapat disimpulkan bahwa debt to equity ratio secara parsial berpengaruh negatife signifikan terhadap harga saham pada perusahaan BUMN sektor perbankan di Bursa Efek Indonesia. Hasil penelitian ini memberikan bukti empiris bahwa semakin tinggi nilai debt to equity ratio perusahaan cenderung akan menurunkan harga saham perusahaan tersebut.

\subsection{Pengaruh Arus Kas Operasi Terhadap Harga Saham}

Berdasarkan uji hipotesis yang menyatakan bahwa Arus Kas Operasi berpengaruh signifikan terhadap harga saham. Hal ini menunjukkan teori yang diutarakan Tendelin (2010:324) menyatakan bahwa data aliran kas perusahaan bisa memberikan pemahaman yang lebih mendalam bagi investor tentang harga saham yang akan terjadi.

Hasil penelitian ini sejalan dengan hasil penelitian yang dilakukan oleh Natalia Dwi Damayanti (2013) dan Irma Samosir (2014). Namun penelitian yang dilakukan oleh Agus Prana (2014) dalam "Pengaruh Arus kas Terhadap Harga Saham Perusahaan Manufaktur di Sektor Aneka Industri yang tercatat di BEI" yang melihat hubungan arus kas operasi dengan harga saham menunjukkan hasil yang negatif.

Berdasarkan hasil pengolahan data diperoleh nilai $t_{\text {statistic }}$ variabel arus kas operasi sebesar 2,773027 dengan nilai probabilitas sebesar 0,0103. Karena nilai $t_{\text {statistic }} 2,773027$ lebih besar dari $t_{\text {tabel }} 2,064$ maka pada tingkat kekeliruan 5\% diputuskan untuk menolak Ho sehingga Ha diterima. Dengan demikian dapat disimpulkan bahwa arus kas operasi secara parsial berpengaruh positif signifikan terhadap harga saham perusahaan BUMN sektor perbankan di Bursa Efek Indonesia. Hasil penelitian ini memberikan bukti empiris bahwa semakin besar arus kas perusahaan dari aktivitas operasi cenderung akan menaikkan harga saham perusahaan tersebut.

\section{SIMPULAN}

Berdasarkan analisis yang telah dilakukan terhadap harga saham 4 Bank BUMN selama 10 hari sebelum publikasi laporan keuangan, hari publikasi laporan keuangan dan 10 hari sesudah publikasi laporan keuangan pada tahun 2009 sampai dengan tahun 2016 di Bursa Efek Indonesia menggunakan analisis linier berganda dan pengolahan data menggunakan program Eviews 8.0 dapat disimpulkan bahwa Berdasarkan hasil pengolahan data dapat disimpulkan bahwa laba bersih, debt to equity ratio dan arus kas operasi secara simultan berpengaruh terhadap harga saham pada perusahaan BUMN sektor perbankan di Bursa Efek Indonesia. Hasil penelitian ini sesuai dengan hasil penelitian yang dilakukan oleh Irma Samosir (2014), Berdasarkan hasil pengolahan data dapat disimpulkan bahwa laba bersih berpengaruh terhadap harga saham pada perusahaan BUMN sektor perbankan di Bursa Efek Indonesia. Hasil penelitian ini sesuai dengan hasil penelitian yang dilakukan oleh Natalia Dwi Damayanti (2013). Hasil ini memberikan bukti empiris bahwa semakin besar laba bersih yang diperoleh perusahaan cenderung akan menaikkan harga saham perusahaan tersebut, Berdasarkan hasil pengolahan data dapat disimpulkan bahwa debt to equity ratio berpengaruh terhadap harga saham pada perusahaan BUMN sektor perbankan di Bursa Efek Indonesia. Hasil penelitian ini sesuai dengan dengan hasil penelitian yang dilakukan oleh Ema Novasari (2013) dan Euis Masopah (2012) dengan hasil debt to equity ratio memiliki pengaruh positif terhadap harga saham dan Berdasarkan hasil pengolahan data dapat disimpulkan bahwa arus kas operasi berpengaruh terhadap harga saham perusahaan BUMN sektor perbankan di Bursa Efek Indonesia. Hasil ini sejalan dengan hasil penelitian yang dilakukan oleh Natalia Dwi Damayanti (2013) dengan hasil arus kas operasi memiliki pengaruh positif signifikan terhadap harga saham. Hasil penelitian ini memberikan 
bukti empiris bahwa semakin besar arus kas perusahaan dari aktivitas operasi cenderung akan menaikkan harga saham perusahaan tersebut.

\section{REFERENSI}

Fahmi, Irham. 2011. Analisis Laporan Keuangan. Bandung : Alfabeta

Husein Umar. (2011). Metode Penelitian Untuk Skripsi Dan Tesis Bisnis (Edisi 2). Jakarta: PT. Raja Grafindo Persada.

Meythi dan Selvy Hartono. 2012. Pengaruh Arus Kas Operasi Terhadap Harga Saham dengan Persistensi Laba sebagai Variabel Intervening. Ilmiah Akutansi ISSN : 20864159.

Novena, Robby, Rinjani, Hedwigis, Esti Riwayati, Nani Fitriani. 2013. The Influence Of Prifitability Ratio In The Stock Price.

Sugiyono. (2011). Metode Penelitian Kuantitatif Kualitatif dan $R \mathcal{E} D\left(12^{\text {th }}\right.$ ed).Bandung: Alfabeta.

http:// bisnis.com. 2013. Stefanus Arief Setiaji. PeringkatUtang Turun:sahamBank BUMN Rontok. Jakarta

http://jaringnews.com. 2012. Achmad Adhito Hatanto. Saham BNI Turun Tipis,Sementara Laba Kuartal III Naik. Jakarta 